\title{
EFEK ANTIOKSIDAN EKSTRAK ETANOL GANGGANG HIJAU (Ulva lactuca L.) TERHADAP KADAR MALONDIALDEHID (MDA) DAN AKTIVITAS ENZIM SUPEROKSIDA DISMUTASE (SOD) HEPAR TIKUS YANG DIINDUKSI $\mathrm{CCl}_{4}$
}

\author{
ANTIOXIDANT EFFECT OF ETHANOLIC EXTRACT OF GREEN \\ ALGAE (Ulva lactuca L.) MALONDIALDEHYDE (MDA) LEVEL \\ AND ACTIVITY OF SUPEROXIDE DISMUTASE (SOD) IN \\ LIVER OF RATS INDUCED BY $\mathrm{CCl}_{4}$
}

\author{
Wahyu Widyaningsih, Riza Sativa, Indra Primardiana \\ Fakultas Farmasi Universitas Ahmad Dahlan \\ J1. Prof. Dr. Soepomo, Janturan, Yogyakarta, Telp. (0274) 379418 \\ Email :widyaningsihwahyu@yahoo.com
}

\begin{abstract}
ABSTRAK
Kerusakan hepar sering disebabkan karena stress oksidatif yang berkaitan erat dengan radikal bebas. Karbon tetraklorida merupakan senyawa toksik sumber radikal bebas penyebab timbulnya stress oksidatif. Adanya kerusakan jaringan tersebut dapat ditandai dengan meningkatnya kadar malonildialdehid (MDA) dan kenaikan kadar enzim superoksid dismutase (SOD). Ganggang hijau (Ulva lactuca L.) mengandung senyawa melatonin yang berfungsi sebagai antioksidan. Penelitian ini bertujuan untuk mengetahui aktivitas ekstrak etanol ganggang hijau (Ulva lactuca L.) sebagai antioksidan dengan parameter kadar MDA dan aktivitas enzim SOD hepar tikus yang diinduksi $\mathrm{CCl}_{4}$. Penelitian ini bersifat eksperimental menggunakan post-test only control group design dilakukan pada 25 hewan uji yang dibagi menjadi lima kelompok, terdiri dari kelompok I (normal) hanya diberi makan dan minum, kelompok II diberi CMC-Na 1\%, kelompok III (kontrol pembanding) diberi tablet curcuma $200 \mathrm{mg} / \mathrm{KgBB}$, kelompok IV dan $\mathrm{V}$ diberi ekstrak etanol ganggang hijau dosis 100 dan $200 \mathrm{mg} / \mathrm{KgBB}$. Perlakuan dilakukan selama 21 hari dan pada hari ke-22 diinduksi $\mathrm{CCl}_{4} \quad 1,0 \quad \mathrm{ml} / \mathrm{KgBB}$ intraperitoneal(i.p) kecuali kelompok I. Setelah 24 jam, hepar tikus diambil dan diukur kadar MDA hepar dengan metode TBARs. Aktivitas enzim superoksida dismutase (SOD) menggunakan metode spektrofotometri. Analisis data menggunakan One way ANOVA dengan taraf kepercayaan 95\% dan dilanjutkan dengan uji LSD. Hasil penelitian menunjukkan bahwa kadar MDA hepar meningkat dan aktivitas enzim SOD menurun secara signifikan akibat induksi $\mathrm{CCl}_{4}(\mathrm{p}<0,05)$. Tablet curcuma dosis $200 \mathrm{mg} / \mathrm{kgBB}$, ekstrak etanol ganggang hijau dosis 100 dan $200 \mathrm{mg} / \mathrm{KgBB}$ dapat menurunkan kadar MDA dan meningkatkan aktivitas SOD hepar tikus yang diinduksi $\mathrm{CCl}_{4}$ secara signifikan $(\mathrm{p}<0,05)$. Kesimpulan penelitian ini adalah ekstrak etanol ganggang hijau (Ulva lactuca L.)
\end{abstract}


mempunyai aktivitas antioksidan dengan menurunkan kadar MDA dan meningkatkan aktivitas enzim SOD hepar tikus yang diinduksi $\mathrm{CCl}_{4}$.

Kata kunci : Ulva lactuca L., melatonin, antioksidan, MDA, SOD

\begin{abstract}
Liver damage is often caused by an oxidative damage strongly associated with free radicals and oxidative stress. Carbon tetrachloride is a toxic compounds as source of free radicals. Tissue damage can be identified by increased levels of malondialdehyde (MDA) and decreased Superoxide Dismutase (SOD) enzyme in the tissue. Green algae (Ulva lactuca L.) contain of melatonin. as antioxidant. The purpose of this study is to determine the effect of ethanol extract of green algae (Ulva lactuca L.) on levels MDA of liver and SOD enzyme activity in rats which induced by $\mathrm{CCl}_{4}$. This study was an experimental study with design post-test only control group design. This study used 25 male rats Wistar. The animals were divided into 5 groups. Group I as normal controls, each of which test animals were not given any treatment, Group II as hepatotoxic group each test animals were given an aqueous suspension of $1 \% \mathrm{CMC}-\mathrm{Na}$. Group III each test animals were given curcuma tablet doses $200 \mathrm{mg} / \mathrm{KgBW}$, group $\mathrm{IV}$ and $V$ were given ethanol extract of green algae (Ulva lactuca L.) at a dose of 100 and 200 $m g / K g B W$ respectively. All groups were treated for 21 days orally. On the day of 22, all groups except group I, were induced with $\mathrm{CCl}_{4} \quad 1,0 \mathrm{ml} / \mathrm{KgBW}$ intraperitoneal IP (i.p). Twenty four hours after inducing time, all rats of every group were sacrificed to take its liver. Rats liver were analyzed using TBARs method to calculate MDA level, SOD activity was analyzed using spectrophotometric. The results obtained were analyzed statistically with One way ANOVA test followed by LSD test, with the significance level of 95\%. The results showed that levels of liver MDA increased and SOD activity decreased significantly due to the induction of $\mathrm{CCl}_{4}(p<0,05)$. Curcuma tablet $(200$ $\mathrm{mg} / \mathrm{KgBW}$ ) and ethanol extract of green algae (Ulva lactuca L.) (100 and 200 $m g / K g B W)$ could reduce levels of liver MDA and increase SOD activity that induced by $\mathrm{CCl}_{4}$ in rats significantly $(p<0,05)$.
\end{abstract}

Keywords : Ulva lactuca L., melatonin, antioxidant, MDA, SOD 


\section{PENDAHULUAN}

Radikal bebas adalah atom atau molekul yang tidak stabil dan sangat reaktif karena mengandung satu atau lebih elektron tidak berpasangan pada orbital terluarnya (Kikuzaki et al., 2002). Radikal bebas berperan dalam terjadinya berbagai penyakit. Paparan radikal bebas dapat menyebabkan terjadinya kerusakan dan kematian sel hepar (Mahdi et al., 2007).

Hepar merupakan organ parenkim dalam tubuh manusia yang paling besar dan sangat penting untuk mempertahankan fungsi hidup dan berperan dalam hampir setiap metabolisme tubuh (Tellingen, 2003). Kerusakan hepar yang bersifat kronis dapat menyebabkan sirosis hati (Crawford, 2007). Berdasarkan data WHO (2004) sirosis hati merupakan penyebab kematian kedelapan belas di dunia, dengan prevalensi 1,3\% (Malau, 2011). Pada tahun 2007, prevalensi penyakit sirosis hati di Indonesia sebesar 1,7\% (Alfiani, 2008).

Kerusakan sel hepar terjadi pada asam lemak tak jenuh fosfolipid membran sel, sehingga terbentuk peroksida lipid. Pada akhir rangkaian degradasi peroksida lipid akan menghasilkan etana, pentana dan malondialdehid (MDA). Malondialdehid ini dapat dijadikan indikator peningkatan peroksida lipid yang terbentuk akibat radikal bebas (Cochrane, 1991). Enzim superoksida dismutase (SOD) merupakan enzim endogen yang berperan untuk menangkap radikal bebas.

Tanaman ganggang hijau (Ulva lactuca L.) mengandung senyawa melatonin (Balzer dan Hardeland, 1996). Melatonin berfungsi sebagai antioksidan, yaitu melalui aksi penangkapan radikal bebas secara langsung dan meningkatkan enzim antioksidan (Reiter et al., 2003). Melatonin mengurangi Reactive Oxygen Species (ROS) seperti ${ }^{\bullet} \mathrm{OH}$, oksigen singlet, $\mathrm{H}_{2} \mathrm{O}_{2}$, radikal peroksil dan asam hipoklorit melalui aksi penangkapan langsung (Zang et al., 1998). Dalam penelitian ini akan diamati efek pemberian ganggang hijau (Ulva lactuca L.) dalam menurunkan kadar malondialdehid (MDA) dan peningkatan aktivitas 
enzim SOD hepar tikus yang diinduksi $\mathrm{CCl}_{4}$.

butanol:piridin $(15: 1 \mathrm{v} / \mathrm{v})$, dan TEP (1,1,3,3-tetraetoksipropan) sebagai larutan standar.

\section{METODE PENELITIAN}

Penelitian ini merupakan penelitian eksperimental dengan rancangan post-test only control group design.

Bahan yang digunakan untuk penelitian ini adalah ganggang hijau (Ulva lactuca L.) yang diperoleh dari pantai Drini Wonosari Yogyakarta yang diekstraksi dengan etanol $96 \%$ (E Merk). Untuk penginduksi radikal bebas digunakan $\mathrm{CCl}_{4} \quad(\mathrm{E}$ Merk) dengan pensuspensi CMC-Na 1\%. Sebagai kontrol positif digunakan Tablet Curcuma (Soho ${ }^{\circledR}$ ). Bahan kimia yang digunakan untuk penetapan kadar SOD adalah buffer batrium karbonat (Merck) $50 \mathrm{mM}$, larutan EDTA $(\mathrm{BDH}) \mathrm{pH} 10$, xantin (Sigma) $10 \mathrm{mM}$, xantin oksidase (Sigma) 0,04 unit, BSA (Sigma) 0,5\%, NBT (Merck) 2,5 mM, dan PBS (Merck) sebagai larutan standar. Bahan kimia yang digunakan untuk penetapan kadar MDA adalah $\mathrm{KCl}$ $1,15 \%$, sodium dodesil sulfat $8,1 \%$, asam asetat $20 \%, \mathrm{NaOH}$, reagen asam tiobarbiturat $0,8 \%, \quad n$ -
Hewan uji yang digunakan adalah tikus jantan galur Wistar dengan berat badan 200-300 gram yang diperoleh dari Laboratorium Farmakologi Fakultas MIPA Laboratorium Farmasi Universitas Islam Indonesia, Yogyakarta.

Jalannya Penelitian

Pembuatan Simplisia

Tanaman ganggang hijau (Ulva lactuca L.) diperoleh dari pantai Drini, daerah Wonosari, DIY. Pengolahan ganggang hijau (Ulva lactuca L.) untuk menjadi serbuk memerlukan beberapa tahapan. Tahapan tersebut adalah: Ganggang hijau dibersihkan dan dicuci dengan menggunakan air mengalir. Ganggang hijau dimasukkan ke dalam wadah berisi air dan didiamkan selama 12 jam fase penyinaran dan 5 jam fase penggelapan, hal ini dilakukan karena kadar tertinggi melatonin diperoleh pada 12 jam fase penyinaran dan 5 jam fase penggelapan (Kolar dan Machackova, 2001). Ganggang hijau 
diambil dari wadah pada 5 jam setelah dimulai fase penggelapan dan dipotong-potong dengan ketebalan 1$5 \mathrm{~mm}$. Potongan-potongan tersebut dijemur hingga kering di bawah sinar matahari dengan ditutupi kain hitam. Pembuatan Ekstrak Etanol Ganggang Hijau (Ulva lactuca L.).

Ganggang hijau yang sudah dalam bentuk serbuk dilakukan ekstraksi dengan cara maserasi, yaitu serbuk ganggang hijau sebanyak 250 gram dibasahi dengan pelarut etanol 96\% sebanyak 1 L, dilakukan pengadukan selama 3 jam, kemudian didiamkan selama 24 jam. Maserat disaring dengan menggunakan corong buchner dan proses maserasi diulangi 2 kali dengan jenis dan jumlah pelarut yang sama. Maserat yang diperoleh diuapkan dengan menggunakan rotary evaporator pada suhu $40^{\circ} \mathrm{C}$, setelah etanol tidak menetes dilanjutkan penguapan dengan menggunakan waterbath hingga diperoleh ekstrak kental. Ekstrak kental yang diperoleh dihitung rendemennya.
Isolasi dan Identifikasi Senyawa Melatonin

Pemurnian senyawa melatonin dalam ekstrak etanol ganggang hijau (Ulva lactuca L.) dilakukan dengan menambahkan $15 \mathrm{ml}$ asam asetat $15 \%$ pada 1,0 gram ekstrak. Larutan kemudian disaring menggunakan kertas saring. Filtrat diekstraksi dengan $50 \mathrm{ml}$ (3 kali) petroleum eter. Sari asam asetat diambil dan ditambah $\mathrm{NH}_{4} \mathrm{OH}$ hingga pH 10. Selanjutnya, larutan diekstraksi dengan $50 \mathrm{ml}$ (2 kali) eter. Sari eter dipisahkan dan diuapkan sampai kering, kemudian dilarutkan kembali dalam pelarut etanol 5,0 ml. Larutan etanol ditotolkan pada plate silika gel $\mathrm{GF}_{254}$ untuk keperluan preparatif dan dielusi dengan menggunakan fase gerak BAW (n-butanol:asam asetat: air) dengan perbandingan 12:3:5. Bercak yang diperoleh dikerok dan dilarutkan dalam etanol, kemudian disentrifuge dan disaring untuk dipisahkan dari endapan silika. Filtrat yang diperoleh disaring dan ditambah etanol hingga 5,0 ml, kemudian dibaca spektranya pada panjang gelombang 200-400 nm 
menggunakan spektrofotometer UV (Fertaveni, 2012).

Hewan percobaan dibagi menjadi 5 kelompok, masing-masing kelompok terdiri dari 8 ekor hewan uji (tikus). Kelompok I (normal) hanya diberi makan dan minum, kelompok II (kelompok hepatotoksik) diberi suspensi CMC$\mathrm{Na} 1 \%$ secara per oral selama 21 hari, kelompok III (kontrol pembanding) diberi suspensi tablet curcuma dengan dosis 200 $\mathrm{mg} / \mathrm{kgBB} /$ hari secara per oral selama 21 hari, kelompok IV diberi suspensi ekstrak etanol ganggang hijau dengan dosis $100 \mathrm{mg} / \mathrm{kgBB} / \mathrm{hari}$ secara per oral selama 21 hari dan kelompok V diberi suspensi ekstrak etanol ganggang hijau dengan dosis $200 \mathrm{mg} / \mathrm{kgBB} / \mathrm{hari}$ secara per oral selama 21 hari. Perlakuan dilakukan selama 21 hari, pada hari ke-22 diberi suntikan $\mathrm{CCl}_{4} \quad 1,0 \mathrm{ml} / \mathrm{kgBB}$ kecuali kelompok I. Setelah 24 jam semua kelompok hewan uji dikorbankan dan hepar tikus diambil untuk dianalisis kadar aktivitas enzim SOD dan kadar MDA.
Pengukuran Kadar Malondialdehid (MDA) Hepar.

Metode pengukuran kadar MDA yang digunakan dalam penelitian adalah metode Thiobarbituric acid reactive substance (TBARs). Prinsip metode ini berdasarkan kepada kemampuan pembentukan kompleks berwarna merah muda antara MDA dan Asam Tiobarbiturat (TBA), (Capeyron et $a l, 2002)$. Satu gram jaringan hepar dihomogenisasi dengan 9,0 $\mathrm{ml}$ larutan $\mathrm{KCl} 1,15 \%$ dengan alat Teflon Potter-Elvehjem homogenizer. Sebanyak 0,2 $\mathrm{ml}$ dari homogenat hepar, ditambah dengan 0,2 $\mathrm{ml}$ sodium dodesil sulfat $8,1 \%$ dan 1,5 $\mathrm{ml}$ larutan asam asetat 20\% sampai $\mathrm{pH} 3,5$ serta $1,5 \mathrm{ml}$ larutan TBA 0,8\%. Campuran tersebut ditambahkan dengan air sampai volume 4,0 $\mathrm{ml}$, dipanaskan pada suhu $95^{\circ} \mathrm{C}$ selama 60 menit, kemudian didinginkan dengan menggunakan air. Setelah dingin, campuran ditambahkan 1,0 $\mathrm{ml}$ air dan 5,0 $\mathrm{ml}$ campuran $\mathrm{n}$ butanol:piridin $\quad(15: 1 \quad \mathrm{v} / \mathrm{v})$ lalu digojok. Selanjutnya disentrifuge dengan kecepatan 4000 rpm selama 
10 menit, lapisan organik diambil dan diukur absorbansinya pada panjang gelombang $532 \mathrm{~nm}$ menggunakan spektrofotometer visibel. Larutan standar yang digunakan adalah 1,1,3,3tetraetoksipropan (TEP) (Ohkawa et al., 1979). Senyawa 1,1,3,3tetraetoksipropan dapat digunakan sebagai standar karena pada suasana asam TEP terhidrolisis menghasilkan hemiasetal dan etanol. Hemiasetal yang terbentuk kemudian terdekomposisi menjadi etanol dan MDA (Conti et al., 1991).

Penetapan Aktivitas enzim SOD

Sebanyak 0,06 $\mathrm{ml}$ supernatan hati direaksikan dengan campuran yang terdiri dari $2,70 \mathrm{ml}$ buffer natrium karbonat $50 \mathrm{mM}$ yang mengandung 0,1 mM EDTA (pH 10); 0,06 ml xantin $10 \mathrm{mM} ; 0,03 \mathrm{ml}$ bovine serum albumin (BSA) 0,5\%; dan $0,03 \mathrm{ml}$ NBT $2,5 \mathrm{mM}$. Selanjutnya dilakukan penambahan xantin oksidase $(0,04)$ unit. Absorbansi yang dihasilkan setelah 30 menit diukur pada panjang gelombang $560 \mathrm{~nm}$. Sebagai larutan kontrol digunakan larutan yang dipakai dalam preparasi sampel hati yaitu PBS yang mengandung 11,5 $\mathrm{g} / \mathrm{L} \quad \mathrm{KCl}$. Aktivitas SOD (\%) dihitung dengan menggunakan persamaan 1 .

$\left[1-\left(\frac{A}{B}\right)\right] \times 1000$

$\mathrm{A}=$ Absorbansi larutan sampel

$\mathrm{B}=$ Absorbansi larutan kontrol

\section{HASIL DAN PEMBAHASAN}

Identifikasi Tanaman

Identifikasi tanaman dilakukan di Laboratorium Biologi Fakultas MIPA Universitas Ahmad Dahlan Yogyakarta. Hasil mikroskopik terlihat adanya fragmen pengenal berupa parenkim yang merupakan ciri khas ganggang hijau (Ulva lactuca L.)

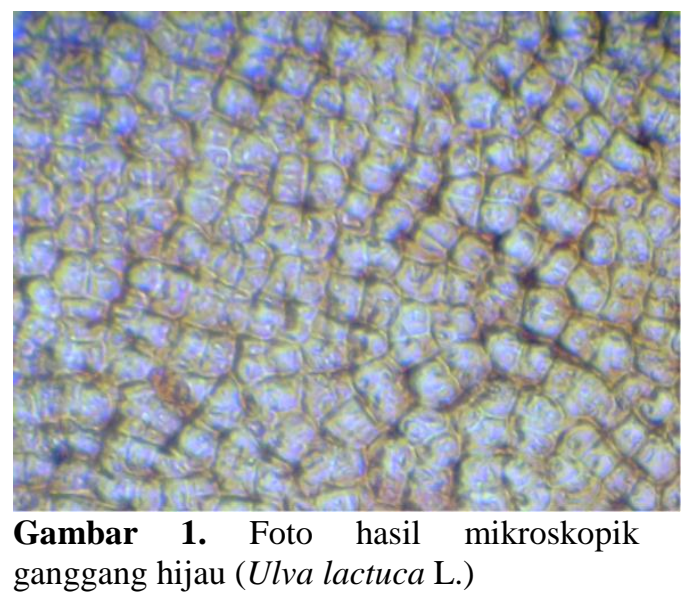




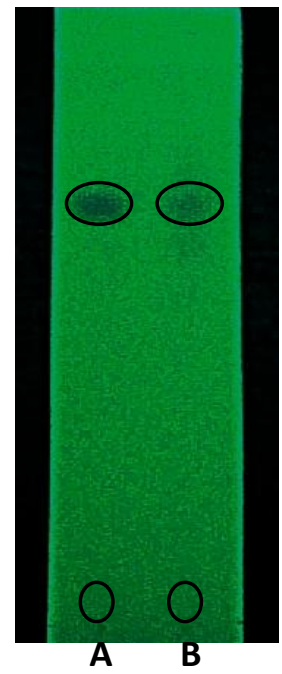

Gambar 2. Hasil identifikasi melatonin pada UV $254 \mathrm{~nm}$ dengan metode KLT. A: Melatonin standar, B: Sampel hasil pemurnian ekstrak etanol ganggang hijau (Ulva lactuca L.)

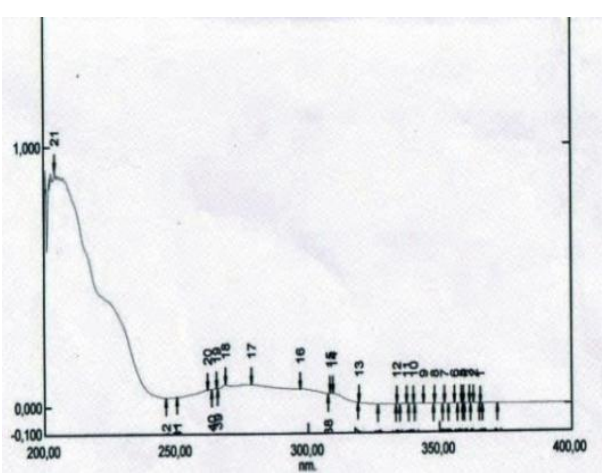

(A)

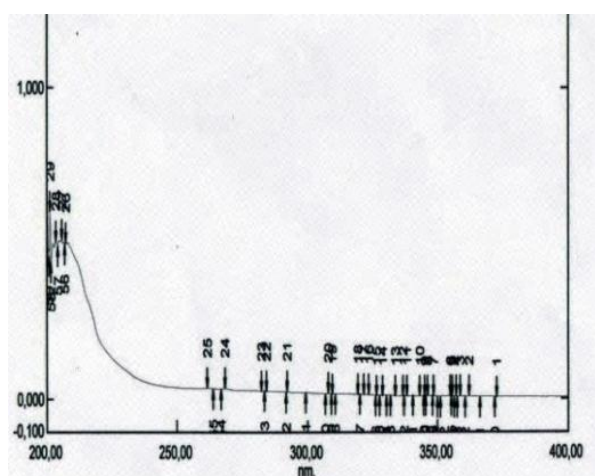

(B)

Gambar 3. Profil spektra. (A) Melatonin baku , (B) Sampel hasil pemurnian ekstrak etanol ganggang hijau (Ulva lactuca L.)

Identifikasi Senyawa Melatonin dengan KLT

Hasil yang diperoleh setelah bercak dideteksi dengan sinar UV $254 \mathrm{~nm}$ menunjukkan adanya kesamaan warna dan harga Rf pada melatonin standar dan sampel hasil pemurnian. Harga Rf melatonin standar dan sampel hasil pemurnian sebesar 0,75 dengan warna bercak ungu. Hal ini menandakan bahwa ada kemungkinan kedua senyawa tersebut adalah senyawa yang sama, yaitu melatonin (Gambar 2). Kepastian adanya senyawa melatonin 
dibuktikan dengan spektra UV pada spektrofotometer UV-VIS.

Berdasarkan gambar tersebut diketahui bahwa melatonin standar dan bercak sampel hasil pemurnian memiliki spektra yang identik. Jadi, dapat disimpulkan bahwa senyawa hasil pemurnian ekstrak etanol ganggang hijau (Ulva lactuca L.) adalah melatonin (Gambar 3).

Hasil penetapan kadar MDA dan Aktivitas enzim SOD

Rata- rata kadar MDA dan aktivitas enzim SOD tiap kelompok perlakuan dapat dilihat pada Tabel I.

Hasil rata-rata kadar MDA dan aktivitas enzim SOD hepar tikus kontrol normal dibanding kelompok hepatotoksik yang diberi $\mathrm{CCl}_{4}$ menunjukkan adanya perbedaan signifikan dengan meningkatnya kadar MDA dan penurunan aktivitas enzim SOD. Hal tersebut dikarenakan terjadi stress oksidatif akibat pemberian $\mathrm{CCl}_{4}$ menyebabkan terjadinya stress oksidatif sehingga meningkatkan proses peroksidasi lipid ditandai dengan peningkatan kadar MDA yang merupakan hasil peroksidasi lipid dan penurunan aktivitas enzim enzim SOD hepar.
Hal ini sesuai dengan teori bahwa $\mathrm{CCl}_{4}$ yang bersifat toksik dalam metabolismenya akan menghasilkan radikal bebas yang lebih reaktif yaitu radikal triklorometil $\left(\mathrm{CCl}_{3}{ }^{\bullet}\right)$ dan triklometilperoksi $\quad\left(\mathrm{CCl}_{3} \mathrm{OO}{ }^{\bullet}\right)$. Radikal bebas tersebut akan berikatan dengan lipid tak jenuh (PUFA) untuk memulai terjadinya peroksidasi lemak, dan peroksidasi akan menyebabkan kerusakan membran lipid dan protein serta menyebabkan penurunan antioksidan (Gutteridge dan Halliwel, 1999). Hal ini didukung teori Batakov dalam khalaf et al. (2008) pada kerusakan hepar akibat induksi $\mathrm{CCl}_{4}$, aktivitas SOD yang berperan dalam melakukan pembersihan "scavenge" pada anion superoksida dan mengubahnya menjadi hidrogen peroksida serta menghilangkan toksisitas radikal bebas, akan mengalami penurunan karena tidak mampu mengimbangi peningkatan peroksidasi lemak dan peningkatan ROS akibat pemberian $\mathrm{CCl}_{4}$.

Tablet curcuma secara signifikan menurunkan kadar MDA dan meningkatkan aktivitas enzim SOD jika dibandingkan dengan 
Tabel I. Rata rata Kadar MDA dan aktivitas enzim SOD hepar tikus setelah pemberian $\mathrm{CCl}_{4}$

\begin{tabular}{lcc}
\hline Kelompok Perlakuan & $\begin{array}{c}\text { Kadar MDA } \\
(\text { nmol/ gram) }\end{array}$ & $\begin{array}{c}\text { Rata-rata Aktivitas Enzim } \\
\text { SOD }(\%) \pm \text { SD }\end{array}$ \\
\hline Kontrol Normal & $0,12 \pm 0,02$ & $72,44 \pm 1,47$ \\
kelompok hepatotoksik & $1,15 \pm 0,06$ & $14,67 \pm 2,10$ \\
Curcuma 200 mg/kgBB/hari & $0,29 \pm 0,02^{*}$ & $53,44 \pm 2,98 *$ \\
EEGH 100 mg/kgBB/hari & $0,77 \pm 0,03^{*}$ & $43,05 \pm 3,17^{*}$ \\
EEGH 200 mg/kgBB/hari & $0,50 \pm 0,02^{*}$ & $67,34 \pm 1,50^{*}$ \\
\hline
\end{tabular}

Keterangan: Berbeda signifikan dibanding kelompok hepatotoksik dengan taraf kepercayaan 95\%

Kelompok hepatotoksik $\quad(\mathrm{P}<0,05)$

Tablet Curcuma adalah salah satu produksi Industri SOHO, mengandung serbuk dari Rhizoma Curcuma, yang mengandung zat aktif kurkumin dan minyak atsiri (Wahyono et al., 2009). Kurkumin dapat menurunkan kadar MDA karena kurkumin mempunyai gugus hidroksi fenolik yang dapat menangkap radikal bebas terutama radikal hidroksil (Tonnesen dan Greenhill, 1992). Hal ini sesuai dengan penelitian sebelumnya yang dilakukan oleh Tristanti et al. (2013) bahwa pemberian tablet curcuma mampu menurunkan kadar MDA hepar tikus Wistar yang diinduksi $\mathrm{CCl}_{4}$.

Pemberian EEGH dosis 100 $\mathrm{mg} / \mathrm{kgBB}$ dan dosis $200 \mathrm{mg} / \mathrm{kgBB}$ selama 21 hari dapat menurunkan kadar MDA dan meningkatkan aktivitas enzim SOD hepar secara signifikan setelah pemberian $\mathrm{CCl}_{4}$. Hasil tersebut menunjukkan bahwa EEGH dosis $100 \mathrm{mg} / \mathrm{kgBB}$ dan dosis $200 \mathrm{mg} / \mathrm{kgBB}$ mempunyai aktivitas antioksidan yang ditunjukkan dengan menurunnya aktivitas peroksidasi lipid membran ditandai dengan penurunan kadar MDA dan peningkatan aktivitas antioksidan endogen yaitu enzim SOD yang menangkap anion superoksida dan mengubah menjadi hidrogen peroksida. Peningkatan aktivitas enzim SOD tersebut diduga terjadi akibat aktivitas zat antioksidan melatonin dalam EEGH. Mekanisme melatonin sebagai antioksidan meliputi penangkapan secara langsung terhadap radikal bebas, menstimulasi enzim antioksidan, meningkatkan efisiensi fosforilasi oksidatif di mitokondria, dan meningkatkan efisiensi antioksidan lain (Reiter et al., 2003). Melatonin 
dapat menetralisir zat radikal dengan

menyumbangkan

elektronnya

bereaksi dengan radikal ${ }^{\circ} \mathrm{OH}$

membentuk senyawa

4-hidroksimelatonin. Melatonin juga dapat menghambat pembentukan peroksinitrit (prekursor radikal) dengan menghambat enzim nitrit oksida sintetase membentuk senyawa $N$-nitrosomelatonin (Dun-Xian et al., 2007). Selain itu, melatonin juga mengurangi stress oksidatif dengan meningkatkan aktivitas enzimantik oksidan seperti SOD, CAT, dan glutationperoksidase (GSH-Px) (Liu, 2000). Hal ini sesuai dengan penelitian yang dilakukan oleh Ozturk et al., (2000), meneliti tentang pengaruh melatonin pada aktivitas enzim superoksida dismutase (SOD) hepar, nitrat serum dan kadar hormon tiroid. Hasil penelitian menunjukkan bahwa tikus yang diinduksi melatonin dosis 10 $\mathrm{mg} / \mathrm{kgBB}$ selama 7 hari terjadi kenaikan aktivitas SOD hepar. Pada penelitian ini, kedua kelompok dosis menunjukkan peningkatan rerata aktivitas enzim SOD dibandingkan dengan kelompok hepatotoksik. Hal ini sesuai dengan teori dimana pemberian antioksidan pada tikus yang diinduksi $\mathrm{CCl}_{4}$ dapat menstimulasi mekanisme perlindungan antioksidan dengan meningkatkan aktivitas SOD di homogenate hepar (Khalaf et al., 2008).

\section{KESIMPULAN}

Pemberian ekstrak etanol ganggang hijau (Ulva lactuca L.) dosis $100 \mathrm{mg} / \mathrm{kgBB}$ dan 200 $\mathrm{mg} / \mathrm{kgBB} \quad$ selama 21 hari menunjukkan adanya aktivitas antioksidan dengan parameter penurunan kadar MDA dan peningkatan aktivitas SOD hepar tikus yang diinduksi $\mathrm{CCl}_{4}$.

\section{DAFTAR PUSTAKA}

Alfiani, E., 2008, Asuhan Keperawatan Pada Tn. S Dengan Sirosis Hepatitis Di Ruang Cempaka BRSUD Sukaharjo, Karya Tulis Ilmiah Mahasiswa, Fakultas Kesehatan Universitas Muhammadiyah Surakarta.

Balzer I., Hardeland R., 1996, Melatonin in algae and higher plants: possible new roles as a phytohormone and antioxidant, Botanica Acta 109, 180-183.

Capeyron, C. Julie., B. Eric., P. Jean., MR. Piere., L.L. Claude, D. Benard, 2002, A diet cholesterol and deflcient in vite incudes lipid peroxidation but 
does not enhace antioxidant enzyme expression in rat liver, jnurt. Biochem. 13:296-301.

Cochrane, G. C., 1991, Cellular injury by oxydant, Am.J.Med.

Conti, M., Morand P.C., Laillain P., Lemonniera A., 1991, Improve fluorometric determination of malondialdehyde, J. Clin. Chem., 37:1273-1275.

Crawford, J.M., 2007, The Liver, Gallbladder, and Biliary Tract; Robbins Basic Pathology 8th ed. New York: Elsevier inc. page 631-632

Dun-Xian T., Lucien C., Manchester, Maria P. Terron, Luis J. Flores and Russel J. Reiter, 2007, One molecule, many derivatives: A never-ending interaction of melatonin with reactive oxygen and nitrogen species?, J. Pineal Res. 42:28-42.

Fertaveni, B. Z., 2012, Penetapan kadar phytomelatonin ekstrak etanol ganggang hijau (Spirogyra sp.) hasil penyarian dengan alat soxhlet dan maserasi secara spektrofotometri, Skripsi, Fakultas Farmasi Universitas Ahmad Dahlan, Yogyakarta.

Gutteridge,J.M.C., Halliwel,B.,1999, Free radicals in Biology and Medicine, Third Edition, New York, Oxford University Press.

Khalaf A.A., Mekawy M.E.M., Moawad M.S., Ahmed A.M., 2008, Comparative Study on the Protective Effect of Some Antioxidant Against $\mathrm{CCl}_{4}$ Hepatotoxity in Rats. Dalam Egyptoan Journal of Natural Toxins,. Egypt: Egyptian Journal. vol 6(1): 59-82

Kikuzaki,H.,Hisamoto,M.,Hirose,K., Akiyama,K.,Taniguchi, H.,
2002, Antioxidants Properties of Ferulic Acid and Its Related Compound, J. Agric.Food Chem, 50: 2161-2168.

Kolar, J. and Machackova, I., 2001, Occurrence and Possible function of melatonin in plants, Endocytobiosis and cell Res 14 (1) : 75-84.

Liu F. HG. TB., 2000, Effect of pineal indoles on activities of the antioxidant defense enzymes superoxide dismutase, catalase, and glutathione reductase, and levels of reduced and oxidized glutathione in rat tissues, Biochem Cell Biol; 78:447 453.

Mahdi C, Aulaniam, Widodo, Sumarno, 2007, Yogurt Sebagai Detoksikan yang Efektif Terhadap Toksisitas Formalin yang Terpapar dalam Makanan, Jurnal Protein, Vol. 15 No. 1.

Malau, A. S., 2011, Karakteristik Penderita Sirosis Hati yang Dirawat Inap di Rumah Sakit Martha Friska Medan Tahun 2006-2010, Skripsi, Fakultas Kesehatan Masyarakat, USU, Medan.

Ohkawa, H., N. Ohishi and K. Yagi, 1979, Assay for lipid peroxidase in animal tissues by thiobarbituric acid reaction. Ana, Biochem, 95:351-358.

Ozturk, G., Coşkun, S., Erbaş, D., \& Hasanoglu, E., 2000, The effect of melatonin on liver superoxide dismutase activity, serum nitrate and thyroid hormone levels. The Japanese journal of physiology, 50(1), 149-153.

Reiter, R.J., Dun-Xian T., Juan C.M., Rosa M.S., Josefa L., Zbigniew 
C., 2003, Melatonin as an

Biochim Biophys Acta; antioxidant: biochemical 1425:469-477.

mechanisms and

pathophysiological

implications in humans, Acta

Biochimica Polonica, Vol. 50

No. 4:1129-1146.

Tellingen, C.V., 2003, Organ

Physiology From a

Phenomenological Point of

View, Louis Bolk Instituut,

Driebergen, pp 89-90.

Tonnesen, H. and Greenhill J., 1992,

Studies on curcumin dan curcuminoids: XXII curcumin as a reducing agents as a radical scavenger,

International Journal of Pharmaceutical, 87:79-87.

Wahyono, J., Arif R.H., Purwantiningsih, 2009, Pengaruh pemberian tablet curcuma terhadap farmakokinetika rifampisin pada tikus, Karya Tulis Ilmiah, Universitas Gadjah Mada, Yogyakarta.

Zang L-Y, Gosma G, Garder H., 1998, Scavenging of reactive oxygen species by melatonin, 